\title{
Software "Image J" Application in Evaluating the Quality of Extracted Raw Wood Assortments
}

\section{Primjena programa Image $J$ za ocjenu kvalitete drvnih sortimenata}

\author{
Original scientific paper • Izvorni znanstveni rad \\ Received-prispjelo: 4. 9. 2013. \\ Accepted-prihvaćeno: 9. 4. 2014. \\ UDK: $630 * 832.151 ; 630 * 832.155$ \\ doi:10.5552/drind.2014.1348
}

\begin{abstract}
The goal of this paper was to investigate the possibility and verify the use of the software product "Image J" for the evaluation of the selected qualitative characters of wood as a renewable natural resource. For this purpose, the qualitative character "false heartwood" in beech wood was selected and evaluated in the sample of 63 logs. The aim was to compare the assessment of this qualitative character as it is performed today, namely by visual evaluation, against the use of the software product "Image J", which is considered to be more precise in assessing this qualitative character. The difference in quality grades of wood assortments between the two methods has also been quantified, as well as the potential economic benefits in the practical use of this software product. The possibilities of its use in the evaluation and measurement of other wood qualitative characters have been described, specifically those in which the quantification of the affected area is decisive. The results clearly demonstrate that the current visual evaluation of these qualitative characters is not adequately precise and that therefore, in some cases, it underestimates the quality of timber.
\end{abstract}

Keywords: raw wood assortments, quality of extracted wood, wood qualitative characters, automated quality assessment

SAŽETAK • Cilj ovog rada bio je istražiti mogućnosti i provjeriti primjenu programa ImageJ za vrednovanje odabranih kvalitativnih obilježja drva kao obnovljivoga prirodnog resursa. Za tu svrhu odabrano je kvalitativno obilježje trupaca bukve, tzv. lažna srž, i ocijenjeno na uzorku od 63 trupca. Cilj je bio usporediti procjenu toga kvalitativnog obilježja metodom koja se danas primjenjuje, tj. vizualnom metodom, s metodom u kojoj se primjenjuje softverski proizvod ImageJ, za koju se predviđa da je preciznija u procjeni toga kvalitativnog obilježja. Određena je razlika u kvaliteti razreda različitih drvnih sortimenata procijenjena tim dvjema metodama, te utvrđene potencijalne ekonomske koristi od praktične primjene toga softverskog proizvoda. Opisane su mogućnosti primjene softvera u ocjenjivanju i mjerenju drugih kvalitativnih obilježja drva, posebno onih u kojima je odlučujuća kvantifikacija površine. Rezultati jasno pokazuju da je sadašnja vizualna procjena kvalitativnih obilježja nedovoljno precizna te da je u nekim slučajevima kvaliteta drva podcjenjena.

Ključne riječi: drvni sortimenti, kvaliteta drva, kvalitativna obilježja drva, automatizirano ocjenjivanje kvalitete

\footnotetext{
Authors are assistant professor and associated profesor at Technical University in Zvolen, Faculty of Forestry, Department of Forest Harvesting, Logistics and Ameliorations, Zvolen, Slovakia. ${ }^{2}$ Author is associated profesor at Technical University in Zvolen, Faculty of Wood Sciences and Technology, Department of Enterprise Management, Zvolen, Slovakia.

Autori su docent i izvanredni profesor Tehničkog sveučilišta u Zvolenu, Šumraski fakultet, Zavod za iskorištavanje šuma, logistiku i poboljšanja, Zvolen, Slovačka. ${ }^{2}$ Autor je izvanredni profesor Tehničkog sveučilišta u Zvolenu, Fakultet za znanost o drvu i drvnu tehnologiju, Zavod za menadžment poduzeća, Zvolen, Slovačka.
} 


\section{INTRODUCTION}

\section{UVOD}

Successful valorization and sale of timber grown and produced is not possible without the precise knowledge of its quantitative and qualitative characteristics (Demko et al., 1993). Problems of wood assortments are closely related to economic issues, as by assorting, decision is made about the valorization and capitalization of forest production capacity. Criteria for the evaluation of wood quality are presented by a system of qualitative characteristics. Raw wood still cannot be evaluated easily only according to positive quality features (e.g., only by species, color, etc.), and negative qualitative characteristics are also used. The evaluation is performed based on quantity and extent of characters (flaws), i.e. according to quantity and extent of normal characters, abnormalities, diseases and wood damage, which impair or in rare cases improve its utilization and valorization. The extent of these negative qualitative characteristics and quantitative dimensions of logs or raw wood are the basic criteria for the classification of wood into different grades and assortments according to industry standards.

Thorough knowledge of technical conditions of the production of wood assortments still does not guarantee the optimal capitalization of raw wood. It includes knowledge of the business environment, competitiveness (Jelačić et al., 2012) and long-term development on the market and price development of wood assortments. These pieces of information are the basis for an optimal evaluation and placement of wood and timber products on the market. Therefore, the optimal classification of wood assortments and a thorough knowledge of both the market and technology used in their production are critical in determining the final capitalization on the market, which is an essential and dominant source of income for the forestry industry in Slovakia.

This paper deals with the evaluation of the qualitative character, false heartwood', according to the current technical conditions and by the application of a modern software product. This software can be used in forestry to analyze the selected qualitative characteristics, particularly their areal extent. Both methods are compared and evaluated in assessing, false heartwood' character, including possible economic effects.

\subsection{Legislative environment of SR}

\subsection{Pravni okvir u Republici Slovačkoj}

For assessing wood quality and its classification into different grades, the system of technical specifications for raw wood assortments is used worldwide. European Union has been seeking to harmonize these technical norms for a long time and to this purpose European standards have been issued. Since EN classifies raw wood assortments not taking into consideration the intended use, they are practically unusable. Each EU country has its own technical specifications, which have a long tradition and these standards are being amended without regard of the common European standards.

The use of standards in SR is regulated by the Act 264/1999 about technical requirements for products and conformity assessment and by the Acts 436/2001 and 254/20031, according to which standards are voluntary and only recommendatory. They become mandatory only in the following cases: 1 . Technical legislation (law, decree, etc.) 2. Legislative act of Office of Standards, Metrology and Testing, 3. Treaty. Thus, standards become legally binding only when the purchasing contract is made between the supplier and customer, meaning that in SR wood can be traded by any technical standard which classifies the quality of wood (Suchomel et al., 2010). This is mostly used by different wood dealers but also by large processing entities.

The second reedition of the main standards for raw timber in 2004 does not make the situation any clearer. These facts affect the overall evaluation of wood in operational practice.

Currently, there are two groups of standards in Slovakia, which classify the quality of wood:

- Standards, which qualitatively classify raw-wood assortments, where the future use is known.

- Standards, which qualitatively classify raw-wood assortments, where the future use is unknown.

The first group includes the standards STN 480055 , STN 48 0056, which qualitatively classify conifers.

\subsection{Detection and evaluation of beech false heartwood \\ 1.2. Otkrivanje i procjena "lažne srži" bukve}

Beech false heartwood is defined as unhealthy red or brown colored false heartwood, sharply defined and ring, flame or starfish shaped, seen on beech logs (STN EN 844-10, 2000).

\section{Evaluation of false heartwood (Klir, 1981)}

Researches have shown that beech false heartwood has same mechanical properties as healthy wood. Wood of false heartwood is hard to impregnate. Marbled heartwood is the most difficult to impregnate. It reduces the yield of higher quality timber. It requires a different processing than in sawmills.

\section{Classification of false heartwood}

Classification of false heartwood, according to shape (Klir 1981):

a) round, mostly irregular oval; - simple, one-zone;

b) marble (mosaic), composed of numerous zones demarcated from each other;

c) double, the outer frost core zone, arising due to low temperatures;

d) radial, with sharp spurs and circumscribed with symptoms of rot beginning;

- star, in the middle of log cut;

- flue placed off-center;

Classification of false heartwood, according to health:

- Healthy false heartwood with unchanged mechanical properties from surrounding wood, with no signs of rot and without significant fungus discoloration.

- Partly healthy false heartwood with an initial stage of rot or with discoloration signs of fungus.

- False heartwood with advanced heart rot on most area of false heartwood. 
- False heartwood with advanced stage of rot on the whole surface of the core with visible wood crushing.

\section{Measuring false heartwood (STN EN 1310, 2000)}

The diameter of the circle surrounding the contaminated area is measured. It is expressed as the percentage of thickness measured on the appropriate head (Fig. 1).

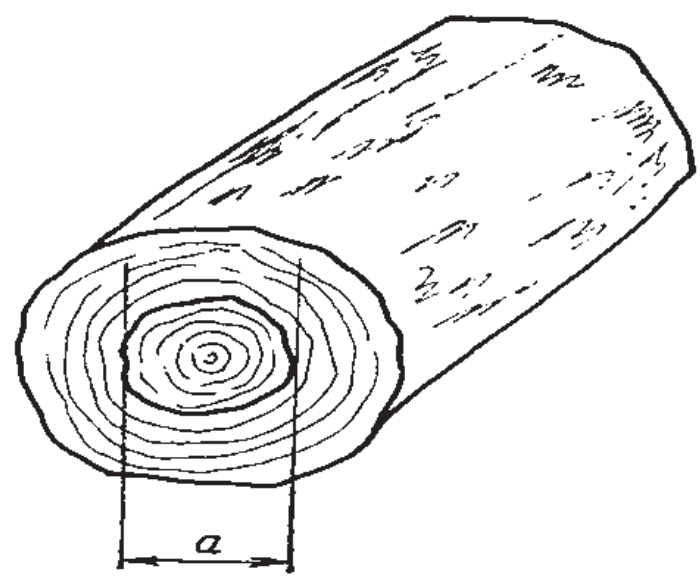

Figure 1 Measurement of false heartwood (STN EN 1310) Slika1. Mjerenje "lažne srži” (STN EN 1310)
The impact of false heartwood on the quality of beech assortments

Table 1 describes the restriction of false heartwood in beech-specific ranges, according to various legislative regulations. The size of beech false heartwood is an important indicator for the classification to quality grade and proper assessment of its thickness share of the front side. Therefore, increased attention should be given to measuring its size. In addition with other quantitative and qualitative features, size of the false heartwood significantly influences the capitalization of raw wood assortments.

\subsection{Application of mobile devices in forestry operations}

1.3. Primjena mobilnih uređaja u šumarstvu

To a certain extent, forestry is a conservative sector. "Classic" areas of computer technology are in use (Tuček, 2011). Currently, the use of mobile devices in Slovak forestry is insufficient. Mobile devices, used in Slovakia, are mostly obsolete. The most used devices are made by Latschbacher (Slančik et al., 2007). Today, there is a variety of new advanced machines and equipment, which significantly facilitate and simplify the measurement and evaluation of qualitative characteristics, and which are connected to high-performance software tools.

Table 1 Assessment of the size of false heartwood of specific assortment quality, according to most commonly used technical standards in SR

Tablica 1. Procjena veličine "lažne srži” u razredima kvalitete konkretnih sortimenata prema najčešće primjenjivanim tehničkim standardima u SR

\begin{tabular}{|c|c|c|c|c|c|c|c|}
\hline $\begin{array}{c}\text { Quality grade } \\
\text { Razred } \\
\text { kvalitete }\end{array}$ & I. & II. & III.A & III.B & III.C & III.D & IV. -V. \\
\hline $\begin{array}{c}\text { STN } \\
480056 \\
(2007)\end{array}$ & $\begin{array}{c}\text { to } 20 \% \text { of } \log \\
\text { butt end area } \\
\text { do } 20 \% \\
\text { površine na } \\
\text { debljem kraju }\end{array}$ & $\begin{array}{l}\text { round and } \\
\text { flame. to } \\
1 / 3 \text { of log } \\
\text { butt end } \\
\text { area } \\
\text { okrugla, do } \\
\text { 1/3 povr- } \\
\text { šine na } \\
\text { debljem } \\
\text { kraju }\end{array}$ & $\begin{array}{c}\text { to } 1 / 3 \text { of log } \\
\text { butt end area, } \\
\text { flame red not } \\
\text { allowed } \\
\text { do } 1 / 3 \\
\text { površine na } \\
\text { debljem kraju, } \\
\text { jarko crvena } \\
\text { nije dopuštena }\end{array}$ & $\begin{array}{l}\text { to } 1 / 2 \text { of log butt } \\
\text { end area, flame } \\
\text { red to } 1 / 3 \text { of log } \\
\text { butt end area } \\
\text { do } 1 / 2 \text { površine } \\
\text { na debljem kraju, } \\
\text { jarko crvena do } \\
1 / 3 \text { površine na } \\
\text { debljem kraju }\end{array}$ & $\begin{array}{l}\text { without } \\
\text { limitation, flame } \\
\text { red to } 1 / 2 \text { of log } \\
\text { butt end area } \\
\text { bez ograničenja, } \\
\text { jarko crvena do } \\
1 / 2 \text { površine na } \\
\text { debljem kraju }\end{array}$ & $\begin{array}{l}\text { not } \\
\text { classified } \\
\text { nije } \\
\text { klasifici- } \\
\text { rano }\end{array}$ & $\begin{array}{c}\text { allowed } \\
\text { dopušteno }\end{array}$ \\
\hline $\begin{array}{l}\text { Conditions of } \\
\text { Lesy SR, š.p. } \\
\quad(2009)\end{array}$ & $\begin{array}{l}\text { to } 20 \% \text { of } \log \\
\text { butt end area } \\
\text { do } 20 \% \\
\text { površine na } \\
\text { debljem kraju }\end{array}$ & $\begin{array}{l}\text { to } 1 / 3 \text { of } \\
\text { log butt end } \\
\text { area } \\
\text { do } 1 / 3 \\
\text { površine na } \\
\text { debljem } \\
\text { kraju }\end{array}$ & $\begin{array}{l}\text { to } 1 / 3 \text { of log } \\
\text { butt end area, } \\
\text { flame red not } \\
\text { allowed } \\
\text { do } 1 / 3 \\
\text { površine na } \\
\text { debljem kraju, } \\
\text { jarko crvena } \\
\text { nije dopuštena }\end{array}$ & $\begin{array}{l}\text { to } 1 / 2 \text { of forhead } \\
\text { area, flame red to } \\
1 / 3 \text { of log butt } \\
\text { end area } \\
\text { do } 1 / 2 \text { površine } \\
\text { na tanjem kraju, } \\
\text { jarko crvena do } \\
1 / 3 \text { površine na } \\
\text { debljem kraju }\end{array}$ & $\begin{array}{l}\text { without } \\
\text { limitation, flame } \\
\text { red to } 2 / 3 \text { of log } \\
\text { butt end area } \\
\text { bez ograničenja, } \\
\text { jarko crvena do } \\
2 / 3 \text { površine na } \\
\text { debljem kraju }\end{array}$ & $\begin{array}{l}\text { not } \\
\text { classified } \\
\text { nije } \\
\text { klasifici- } \\
\text { rano }\end{array}$ & $\begin{array}{c}\text { allowed } \\
\text { dopušteno }\end{array}$ \\
\hline $\begin{array}{c}\text { Quality grade } \\
\text { Razred } \\
\text { kvalitete }\end{array}$ & F-A & & F-B & \multicolumn{3}{|c|}{ F-C } & F-D \\
\hline $\begin{array}{c}\text { STN } \\
\text { EN 1316-1 }\end{array}$ & $\begin{array}{c}\leq 20 \% \text { log butt } \\
\text { end area, flame } \\
\text { red not allowed } \\
\leq 20 \% \text { povr- } \\
\leq \text { sine na debljem } \\
\text { kraju, jarko } \\
\text { crvena nije } \\
\text { dopuštena }\end{array}$ & \multicolumn{2}{|c|}{$\begin{array}{c}\leq 30 \% \text { log butt end area, } \\
\text { flame red core in } \% \\
\text { thickness } \leq 10 \% \\
\leq 30 \% \text { površine na debljem } \\
\text { kraju, jarko crvena srž } u \\
\text { postocima debljine } \leq 10 \%\end{array}$} & \multicolumn{3}{|c|}{$\begin{array}{c}\text { is allowed, flame red false heartwood in } \% \text { of } \\
\qquad \log \text { butt end area } \leq 40 \% \\
\text { dopušteno, jarko crvena lažna srž u postocima } \\
\text { površine na debljem kraju } \leq 40 \%\end{array}$} & $\begin{array}{l}\text { is allowed } \\
\text { dopušteno }\end{array}$ \\
\hline
\end{tabular}


Programs developed and used in mobile devices are primarily applied in processing and recording of timber. New types of mobile devices (e.g. the Trimble Nomad) make new software solutions possible because of their modern interface. In the future, it may be possible to consider software implementation of various technical specifications, possibly with photographic documentation of typical quality characters, or with the implementation of software applications that will allow evaluating and measuring qualitative characteristics based on a digital image. (e.g. ImageJ software product).

These possibilities would certainly increase the productivity of workers in handling the wood stock and expand their opportunities to make the right decisions for the best capitalization of wood in order to maximize the generated profit of sold assortments, including an efficient control system. The qualitative characteristics (of wood) must meet the requirements of customers in the context of comprehensive quality management, achievement of economic efficiency and therefore profitability. High quality of specific products can bring the company a significant competitive advantage (Koprolčec et al., 2012; Merkova et al., 2012).

\section{MATERIAL AND METHODS} 2. MATERIJAL I METODE

\subsection{Examined material}

2.1. Istraživani materijal

For comparative analysis, beech false heartwood was selected as qualitative character, since it is a relatively frequent character with variable dimensions that may significantly affect the final quality of raw wood assortments.

Qualitative analysis was made of a total of 567 pieces of beech from the University forest company TU Zvolen, from district forest areas: Tŕnie, Mláčik, L'ubica, Sekier, Ostra Luka, Blážová, Čertove Kúty, Geberanica, Bukovina, Podzámčok, Hákovo, and Michalková. The character of false heartwood occurred in 340 (60\% occurrence) assortments with an average size of $15.9 \mathrm{~cm}$ circular area. Out of 340 units with the occurrence of beech false heartwood, 63 selections were chosen for the analysis by software ImageJ, and incidence of false heartwood on the log butt end was photographically recorded.

\subsection{Evaluation of false heartwood according to STN EN 1310}

2.2. Procjena "lažne srži" prema normi STN EN 1310

The size of false heartwood was determined on all 63 logs according to STN EN 1310, as described in section 1.2. Consequently, the measured values were expressed as percentages of false heartwood on the log. False heartwood was measured with the calibrated caliper and band.

\subsection{Evaluation of false heartwood by use of} software product ImageJ

2.3. Procjena "lažne srži” primjenom programa ImageJ

All 63 logs were assessed on the basis of the known log thickness in $\mathrm{cm}$, which is called reference

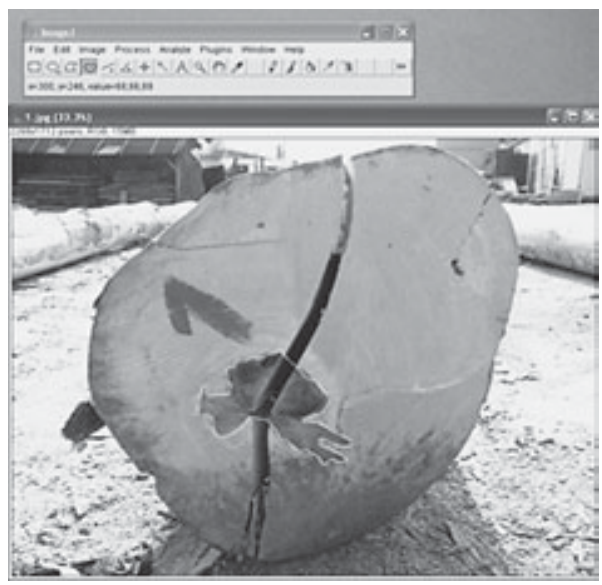

Figure 2 Analysis of false heartwood by software product Image $\mathrm{J}$

Slika 2. Analiza "lažne srži” programom ImageJ

dimension and the program needs this parameter to calculate the area in $\mathrm{cm}^{2}$.

In ImageJ, the scale for the calculation of the surface area of the log butt end, as well as the surface area of false heartwood, is determined with a real reference dimension - the log thickness in $\mathrm{cm}$. The program calculates the surface area of the log butt end, as well as the surface area of false heartwood, after digital bordering. Log butt end area and false heartwood area are bordered by the mouse on a digital photography in program ImageJ (Fig. 2). After the calculation of the surface areas in $\mathrm{cm}^{2}$, it is easy to express the percentage of false heartwood in the total surface area.

Qualitative evaluation took place in log conversion depot Lieskovec from June 15, 2012 to Aug. 31, 2012.

\subsection{Determination of volume and price for raw wood assortments}

\subsection{Određivanje volumena i cijene drvnih sortimenata}

The volume of assortments was determined individually by Smalian formula (1):

$$
v=\frac{\pi}{4} \cdot \frac{d_{0}{ }^{2}+d_{n}{ }^{2}}{2} \cdot L
$$

Where:

$v$ - log volume in $\mathrm{m}^{3}$

$d_{0}-\log$ thickness (thicker end) in $\mathrm{m}$

$d_{n}$ - stud thickness (thinner end) in $\mathrm{m}$

$L$ - length of $\log$ in $\mathrm{m}$

Each log was qualitatively classified according to the size of qualitative character in terms of STN 480056 of 2007. Classification was made with respect to the size of false heartwood detected, according to STN EN 1310 and according to the evaluation by software ImageJ.

For each log, the price was determined per $1 \mathrm{~m}^{3}$ based on the volume and average price (second quarter of 2012) of beech wood in forest public entities with the dominant market share in Slovakia. The prices of assortments are without VAT (tax) at log conversion depot, and they were quoted from "Newsletters National Forest Centre" (Brezinova, 2012). 
In cases where assessment of the size of false heartwood caused a different classification into qualitative grades, by either of the used methods, a price difference was calculated for the specific log.

Due to the limited scope of this paper, only the local market was considered. Therefore, long-term price development of wood assortments in the surrounding countries was not reflected in this paper. Only domestic prices of the second quarter of 2012 were used.

\subsection{Used tools}

2.5. Upotrijebljeni alati

For simple calculations and graphical evaluation, MS Excel 2010 was used. A steel meter (band) was used to measure the size of false heartwood, and a standardized caliper was used to measure the assortment thickness. Photographic documentation was made with the digital camera SONY DSC - P41 with effective pixel count of 4,065,000 and lens with a focal length $f=5.0$ $\mathrm{mm}$. Printed graphics and other evaluations were performed by software product ImageJ $1.37 \mathrm{v}$.

\section{RESULTS AND DISCUSSION}

\section{REZULTATI I RASPRAVA}

\subsection{Analysis of false heartwood according to STN EN 1310}

\subsection{Analiza "lažne srži" prema STN EN 1310}

The average size of false heartwood, measured by STN EN 1310, was $19.2 \mathrm{~cm}$ with an average log thickness of $42.4 \mathrm{~cm}$. The average percentage area of false heartwood was therefore $44.5 \%$. According to STN EN 1310 , the largest size of false heartwood was recorded in the analyzed $\log$ No. $26(60 \mathrm{~cm})$. The smallest false heartwoods were recorded on logs No. 6 and $49(5 \mathrm{~cm})$. The largest percentage area of false heartwood on the $\log$ was recorded in the analyzed $\log$ No. 26 (90.91\%), and the smallest on log No. 6 (9.49\%).
The disadvantage of the analysis according to STN EN 1310 is that it does not reflect the irregularity of false heartwood surface. It provides accurate results for regular (round) shape of false heartwood. The least accurate results are those for very irregular shapes of false heartwood. Under these conditions, this method systematically overestimates or underestimates the assessment, and thus creates incorrect determination of false heartwood proportion depending on log thickness. This may then result in a lower grade classification, which basically means worse capitalization of wood assortments and smaller profit from its sale. On the basis of objective assortment classification (better grades), better revenues would actually be achieved. The size of false heartwood in $\mathrm{cm}$, measured in accordance with STN EN 1310, for all the analyzed assortments are shown in Fig. 3.

\subsection{Analysis of false heartwood according to Image J}

3.2. Analiza "lažne srži" primjenom programa ImageJ

On the basis of the reference dimension, thickness of $\log$, the program calculated the surface area of $\log$ butt end and false heartwood surface in $\mathrm{cm}^{2}$, and then expressed as percentage of false heartwood on the $\log$ butt end. The surfaces of false heartwood in $\mathrm{cm}^{2}$ computed by ImageJ software are presented in Figure 4. The largest surface of false heartwood was recorded on $\log$ No. 26 and the smallest on $\log$ No. 6, which was confirmed by the analysis made in accordance with STN EN 1310. For qualitative classification, the percentual share in the log surface is important.

The largest percentage of false heartwood was recorded on $\log$ No. $26(60.49 \%)$, and the smallest percentage on $\log$ No. $6(0.3 \%)$. These results confirm that the analysis made by the software product and assessment according to STN EN 1310 are much more accurate, especially for very irregular false heartwood,

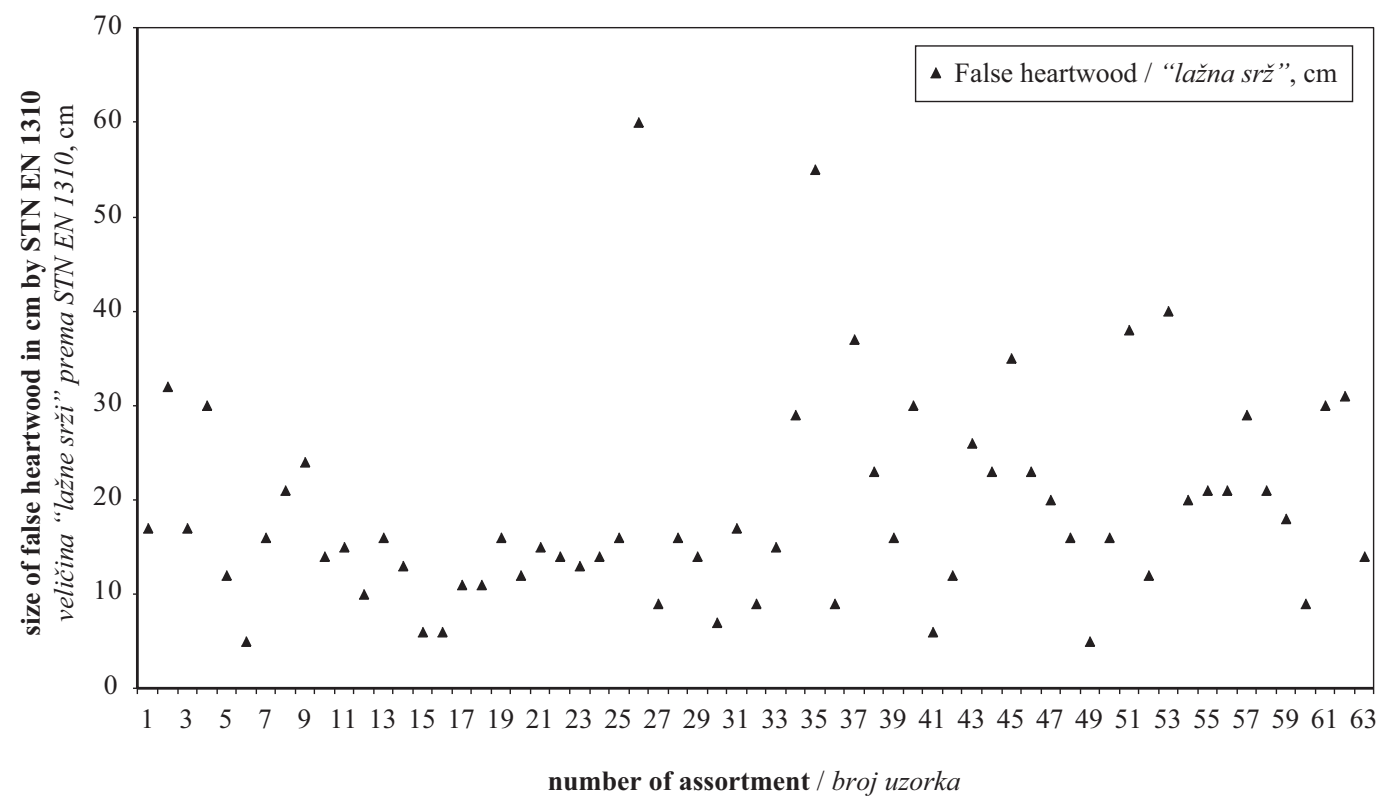

Figure 3 Size of false heartwood in cm according to STN EN 1310

Slika 3. Veličina "lažne srži" u centimetrima prema STN EN 1310 


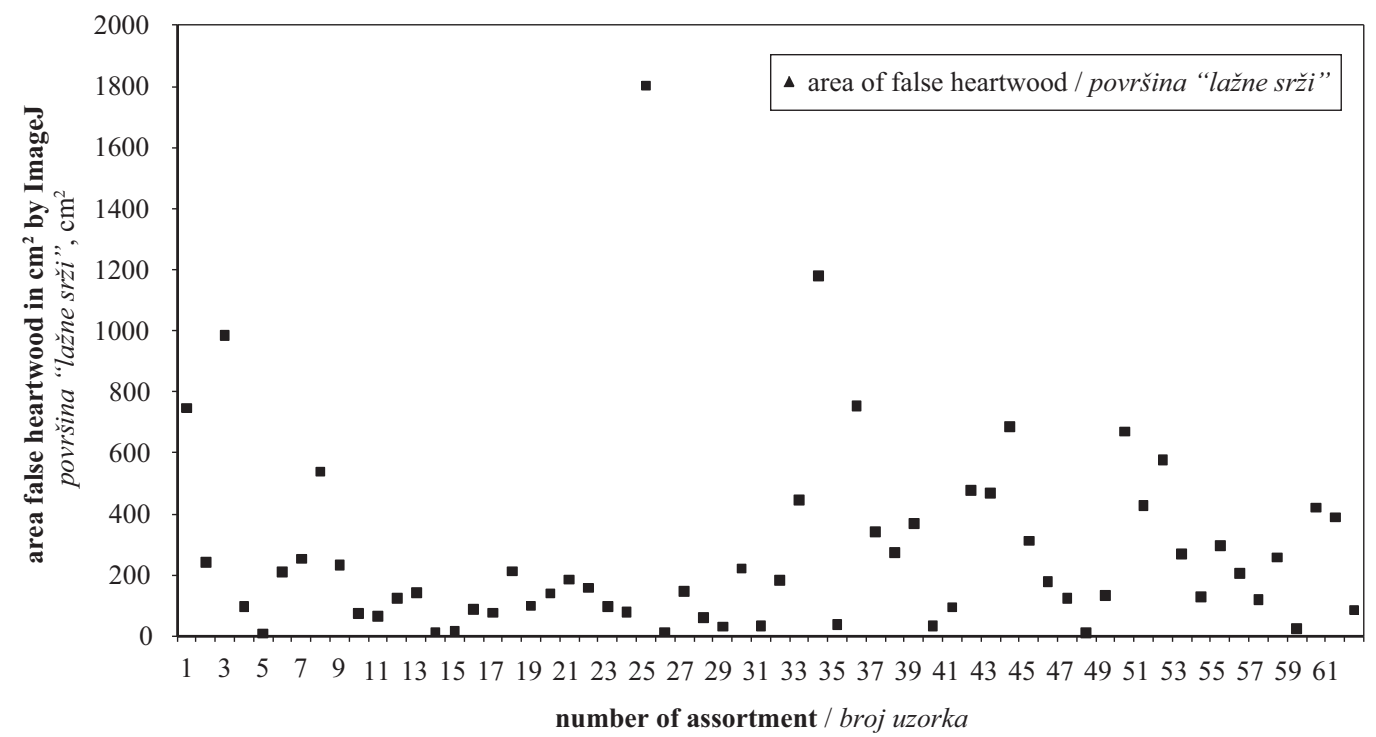

Figure 4 Areas of false-core in $\mathrm{cm}^{2}$ by Image

Slika 4. Površina "lažne srži" izražena u $\mathrm{cm}^{2}$ dobivena primjenom programa ImageJ

where the area of damage is systematically overestimated

\subsection{Comparative Analysis}

\subsection{Komparativna analiza}

The results of comparative analysis show that the assessment of false heartwood according to STN EN 1310 systematically overestimates the area of irregular false heartwood, because it is considered as regular shape, which is almost never the case with false heartwood. The results of comparative analysis confirmed that taking into account 63 logs, the average difference of false heartwood area on the log of each assortment was $28.2 \%$ (i.e. false heartwood evaluated by ImageJ was on average $28.2 \%$ smaller than that assessed according to STN EN 1310). In some cases, this difference has significant influence on potential classification of assortments into quality grades. The average percentage size of false heartwood evaluated according to STN EN 1310 was $44.6 \%$. The average percentage of false heartwood, evaluated by software ImageJ, was $16.37 \%$. The average butt end area of the log, calculated by ImageJ, was $1605.700 \mathrm{~cm}^{2}$ and the average area of false heartwood was $272.319 \mathrm{~cm}^{2}$.

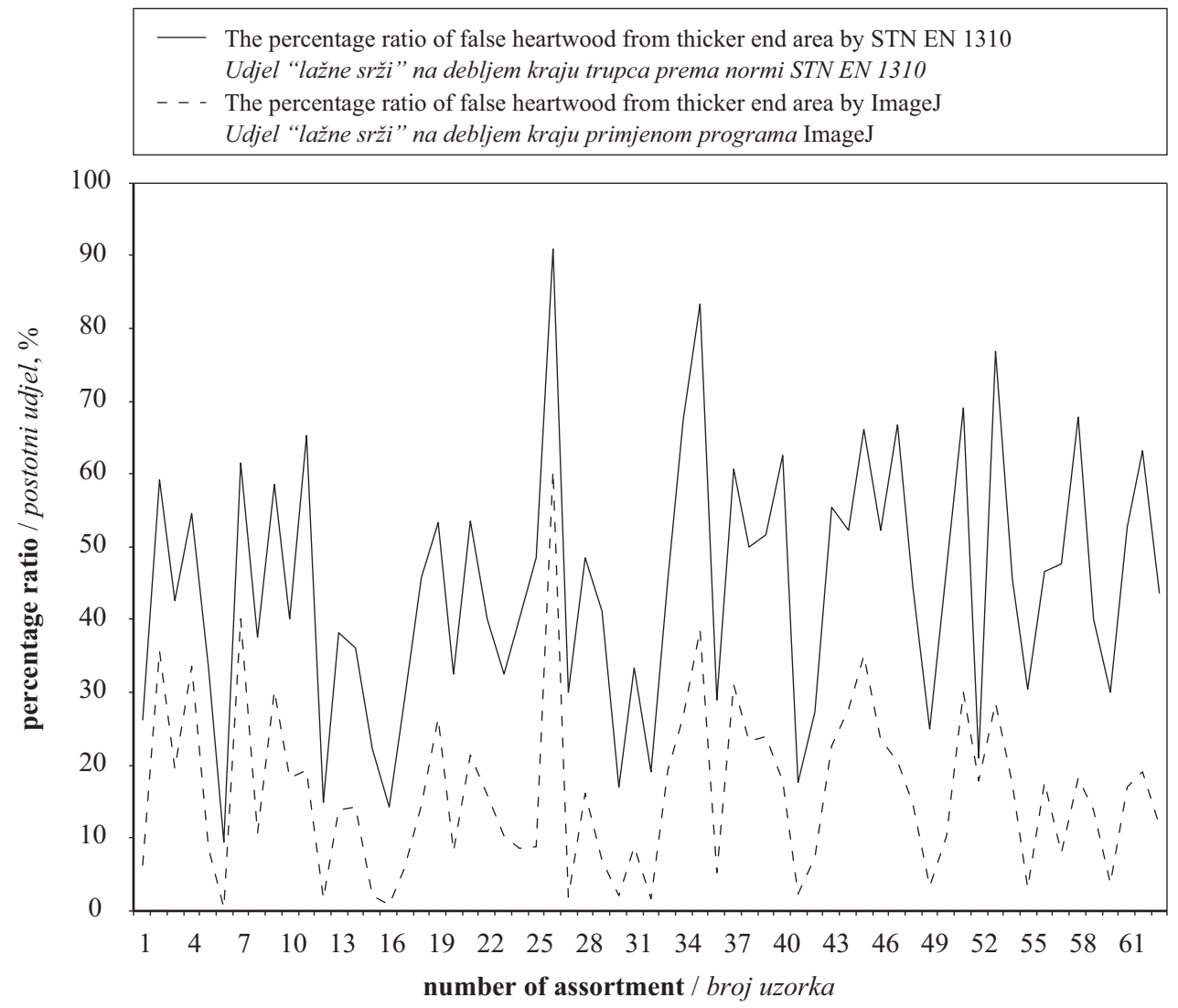

Figure 5 Percentages of false heartwood on total log area according to STN and program ImageJ

Slika 5. Postotak površine "lažne srži" na ukupnoj površini trupca prema normi STN dobiven primjenom programa ImageJ 


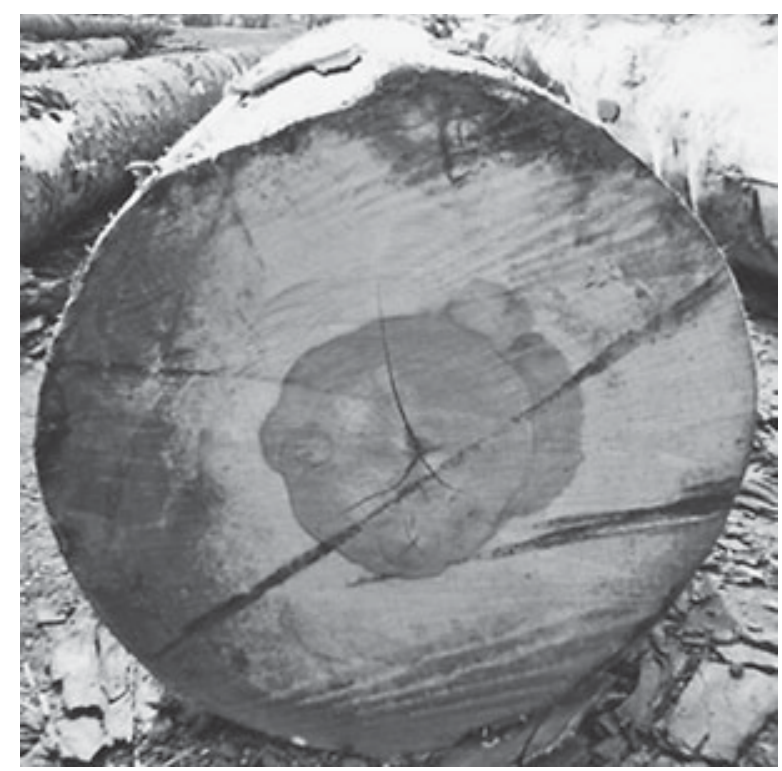

Figure 6 Analyzed log No. 52

Slika 6. Analizirani trupac broj 52

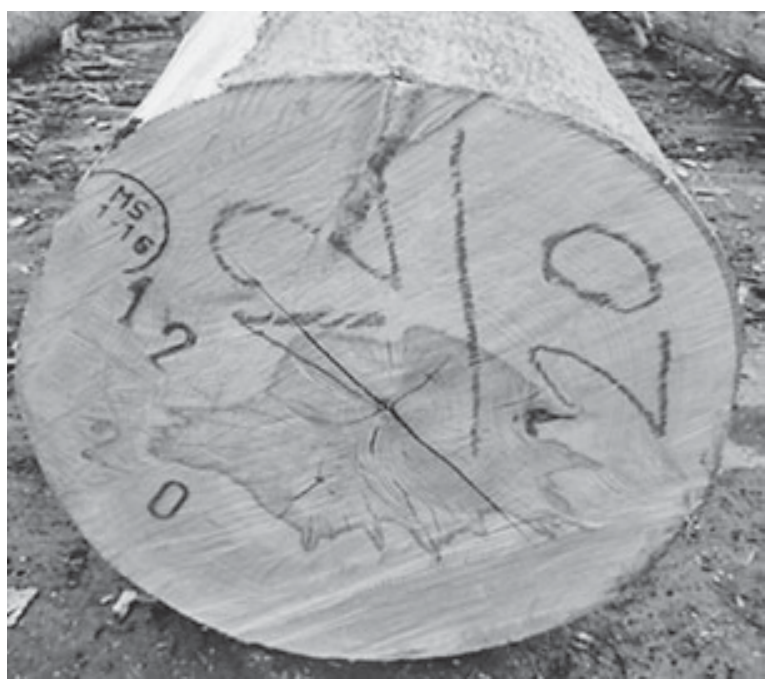

Figure 7 Analyzed log No. 58

Slika 7. Analizirani trupac broj 58

Figure 5 graphically represents percentages of false heartwood according to both methods (STN and ImageJ). For better clarity and illustration of differences between these two methods, the results were connected into curves. The image clearly shows systematic overestimation of false heartwood share according to STN EN 1310. The smallest difference between these two methods was recorded with $\log$ No. 52 with $\log$ thickness of $57 \mathrm{~cm}(3.24 \%)$, probably due to relatively regularly shaped false heartwood (Fig. 6). The analysis of other logs confirmed that differences between these two methods are smaller when false heartwood is smaller and more regular; this confirms the fact that the assessment according to STN EN 1310 achieves the desired accuracy only when false heartwood is small and regularly shaped. Conversely, the biggest difference between methods is recorded when false heartwood is at the larger butt end of the log and of very irregular shape, smaller in proportion to log butt end area (49.6\% difference with $\log$ No. 58 - Fig. 7).
The assessment of irregular false heartwood according to STN EN 1310, significantly overestimates its actual dimensions, which in practice results in the classification of logs to lower quality grades for most assortments with false heartwood. Based on the actual size of false heartwood, according to software ImageJ it is possible to classify some logs into better grades, and thus achieve better price for wood and higher level of capitalization of assortments in operational practice.

This software product could be used in feedback analysis and quality control of manufactured and shipped timber assortments i.e. in auctions and research, of course, provided that the photographic documentation is available.

\subsection{Economic benefits of software deployment 3.4. Ekonomska korist od primjene programa}

The total volume of analyzed assortments was $39.62 \mathrm{~m}^{3}$ (Smalian calculation formula). All assortments were qualitatively classified according to STN 480056 of 2007 into appropriate quality grades. The assessment of the proportion of false heartwood in log butt end had significant impact on classification into different grades. Up to 22 units were classified in the same quality category by both types of analyzes. In other cases, the evaluation of false heartwood by ImageJ resulted in classification to better quality grades (sometimes two grades better). Percentages of assortments in specific quality grades for both assessment methods of false heartwood are shown in Figure 8.

On the basis of volume and price per $1 \mathrm{~m}^{3}$ (last quarter 2012), the final price was calculated for each assortment. Overall evaluation of the sample determined with classical assessment of false heartwood according to STN EN 1310 was estimated at $€ 2,036.83$. By assessing the false heartwood according to ImageJ, the overall assessment of the sample was $€ 2,436.37$. Difference is $€$ 399.54. On average, higher capitalization of about $10.1 € . \mathrm{m}^{-3}$ could be achieved when assessing false heartwood according to software "Image J". Maximum $22 \mathrm{~m}^{3}$ of assortments can be loaded on one truck. In this case, the economic benefit of one load can be quantified approximately to $€ 300.30$. The prices of assortments used for the calculation were the following (Brezinova, M. 2012): Assortment II. grade $89.12 € \cdot \mathrm{m}^{-3}$, assortment III.A grade $69.27 € \cdot \mathrm{m}^{-3}$, assortment III.B grade 55.11 $€ \cdot \mathrm{m}^{-3}$, assortment III.C grade $44.96 € \cdot \mathrm{m}^{-3}$, assortment of fiber and other industrial wood $36.93 € \cdot \mathrm{m}^{-3}$.

In practice, the costs of implementing this method only include the prices of mobile devices, which vary depending on the equipment, starting at $€ 1,300$ per 1 piece. The costs of digital camera are relatively low. The software is free, and freely distributable, meaning that after purchasing a mobile device, the costs are rentabile after dispatching about $173 \mathrm{~m}^{3}$. This conclusion would only apply if the entire amount was assessed by this one mobile device and the resulting assortment quality affected only the qualitative character 'false heartwood'. When several characters (their area) are assessed, the effectiveness of this method is multiplied. 


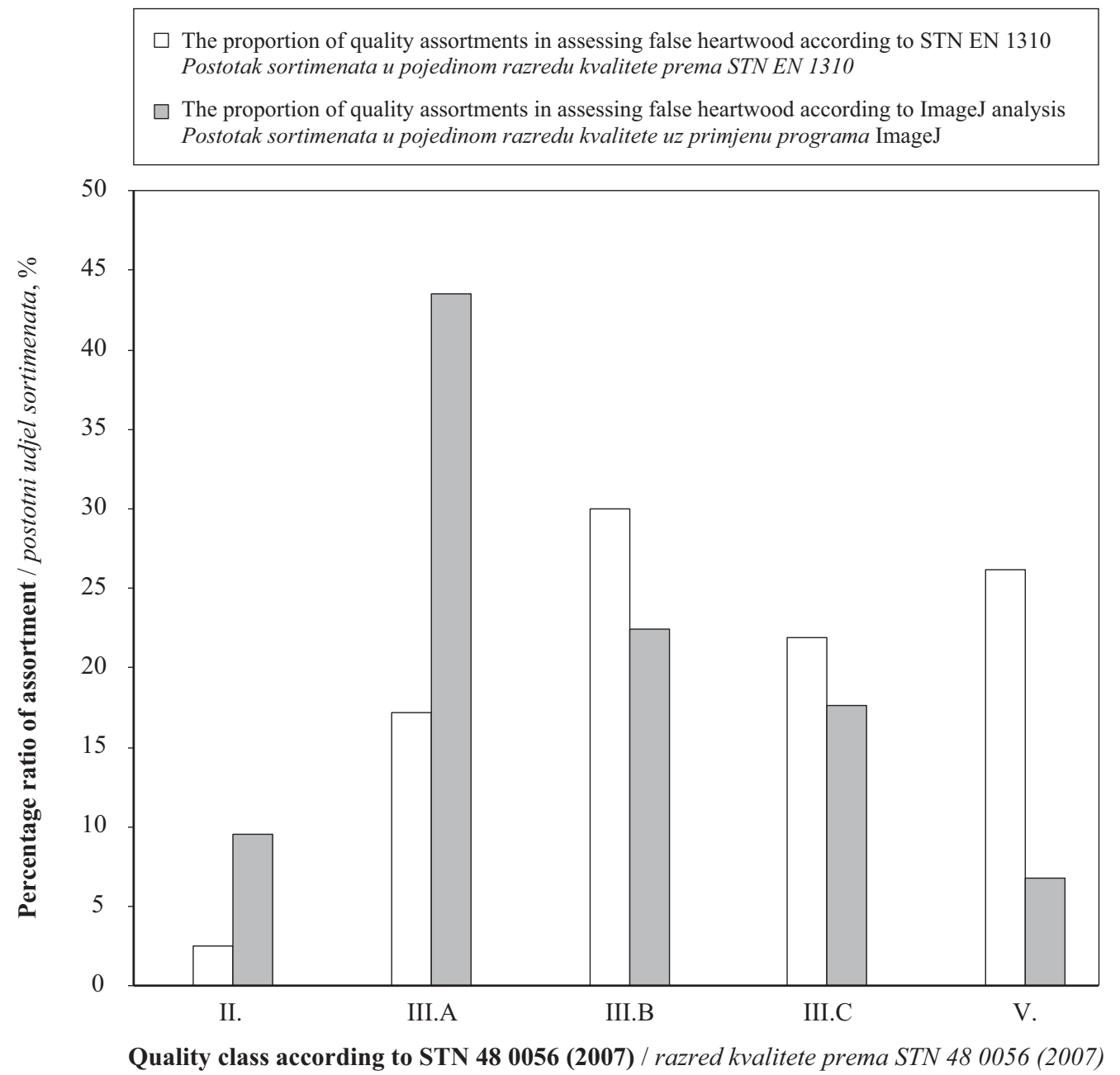

Figure 8 Percentages of assortments in quality grades by assessment of false heartwood according to STN EN 1310 and Image J

Slika 8. Postotak sortimenata u pojedinom razredu kvalitete procjenom "lažne srži” prema normi STN EN 1310 i uz primjenu programa ImageJ

\section{CONCLUSION \\ 4. ZAKLJUČAK}

The results presented in this paper document the significant impact that the increased focus on accurate assessment of negative qualitive characters of wood will bring in near future, particularly in view of potential economic benefits. Some countries already have legislative regulations for electronic timber sorting and more accurate assessment of negative qualitative characteristics (e.g. Austria). The first CT scanners are already applied (e.g. company Microtec), providing perfect measurement and evaluation of all wood qualitive characters that are visible on log surface or hidden inside. It can be assumed that this trend will continue and timber traders, who want to sell wood profitably, will focus on opportunities to minimize the negative evaluation of timber regarding the characters and thus reach its higher value (Motik et al., 2008).

Although in Slovakia the use of advanced technologies in forestry sector is not at the required level, change can be expected in near future. Therefore, there is room for possible deployment of technologies, which would allow to forestry to get more revenue be- cause the sale of wood assortments is the dominant source of its income. Such technologies include the tested software "ImageJ" along with mobile devices and other devices of modern technology.

In view of the income from timber sales, prices and market developments are also important. Recently, they have been affected by global economic crisis and, in Slovakia particularly, also by poor structure of processing industry. Forestry companies, if they want to get the most revenue, will have to make marketing analysis and research of long-term price trends. These activities are not implemented in our forestry companies. The interest in renewable energy resources and research of its energy characteristics will be constantly growing (Dzurenda et al., 2012). Continuous technological development and progress will bring new and effective wood processing options of raw wood material, enabling the reduction of the requirements on overall wood quality (Teischinger, 2010). Development in the last 300 years only confirms this finding (Teischinger, 2010).

Global climate and economic changes will bring in future further turbulences on the market of timber and renewable energy sources, and so the issue of its capitalization will increase in importance. 


\section{Acknowledgments - Zahvala}

This paper was based on research results of the project KEGA No. 016TUZ-4/2012 Multimedia education centre for improving the possibilities of production of higher quality raw wood assortments; ITMS: 26220120069 Centre of excellence for decision support in forest and land.

\section{REFERENCES}

\section{LITERATURA}

1. Brezinová, M., 2012: Vývoj priemerných cien sortimentov a dodávok surového dreva za 2. štvrt'rok 2012, In: Spravodajca Národného lesníckeho centra, Informačný list č. 2/201, 2-14.

2. Demko, J.; Suchomel, J., 1993: Prvotné spracovanie a zhodnotenie dreva a ostatnej produkcie lesa, Správa pre záverečnú oponentúru etapy vedeckého projektu $\mathrm{AL}$ - I $-03 / 05$, Technická univerzita vo Zvolene, 19 p.

3. Dzurenda, L.; Bartko, M.; Ridzik, L., 2012: Energetic characteristics green chips made of branches of wood species Populus x euroamericana clone Koltay grown on plantations. In: Acta Facultatis Xylologiae, 54(2): 115122.

4. Ferreira, T.; Rasband, W., 2012: ImageJ User Guide. [online] 198 pp. available at address: http://rsbweb.nih.gov/ ij/docs/guide/user-guide.pdf. [7. 6. 2013].

5. Jelačić, D.; Oblak, L.; Petrovič, S.; Moro, M.; Pirc Barčić, A.; Ćošić, V.; Meloska, Ž., 2012: Wood Sector Media Promotion in Some South-East European Countries. Drvna industrija 63(3): 195-203.

6. Klír, J., 1981: Vady dřeva, SNTL Praha, 232 p.

7. Koprolčec, M.; Motik, D.; Oblak, L., 2012: Insurance Models of Wood Sector Companies. Drvna industrija 63(3): 177-186.

8. Merková, M.; Drábek, J.; Jelačič, D., 2012: Determinants of Effects of Foreign Direct Investment in Terms of Slovak Republic and Wood-Processing Industry of Slovakia. Drvna industrija 63(2): 129-142.

9. Motik, D.; Carev-Laškarin, V.; Kocbek-Nižetić, M.; Grladinović, T., 2008: Analysis of the Importance of Crafts and Freelance Businesses in the Development of Wood Industry. Drvna industrija 59(4): 163-167.
10. Slančík, M.; Suchomel, J., 2007: Propozycja projektu modernizacji prowadzenia ewidencji gospodarstwa leśnego, ewidencji zapasów i operatywnego kierowania odwozem i sprzedażą surowego drewna, In: Prace Komisji nauk rolniczych, leśnych $i$ weterynaryjnych PAU, Użytkowanie maszyn rolniczych i leśnych, Tom 1. Nr. 9 (2007), s. 167-175. - Kraków : Polska Akademia Umiejętności.

11. Suchomel, J.; Gejdoš, M., 2010: The influence of selected factors on the occurrence of false heartwood in beech (Fagus sylvatica). In: Acta Facultatis Xylologiae Zvolen 52(1): 5-13.

12. Teischinger, A., 2010: The development of wood technology and technology developments in the wood industries-from history to future. In: European Journal of Wood and Wood Products, 2010, p. 1-7, Article in press.

13. Tuček, J., 2011: Geoinformatika a geoinformačné technológie v precíznom lesníctve. Vedecká monografia. TU Zvolen. $166 \mathrm{p}$.

14. ***Zákon č. 264/1999 Z. z. O technických požiadavkách na výrobky a o posudzovaní zhody a o zmene a doplnení niektorých zákonov v znení 436/2001 Z.z. a 254/2003 Z. z.

15. ***STN 48 0056. Kvalitatívne triedenie listnatej gul'atiny. 2007.

16. ***STN EN 1310. Gul'atina a rezivo. Metóda merania znakov. 2000.

17. ***STN EN 1316-1. Listnatá gul'atina. Kvalitatívne triedenie. Čast' 1: Dub a buk. 2000.

18. ***STN EN 844-10. Gul’atina a rezivo. Názvoslovie. Čast' 10: Termíny pre sfarbenie a hubové ochorenia. 2000.

\section{Corresponding address:}

Ing. MILOŠ GEJDOŠ, Ph.D.

Department of Forest Harvesting, Logistics

and Ameliorations

Faculty of Forestry

Technical University in Zvolen

T. G. Masaryka 24

96053 Zvolen, SLOVAKIA

e-mail: gejdos@tuzvo.sk 